\title{
Wayne Ayres Wilcox
}

1932-1974

The death of Wayne Ayres Wilcox, with his wife, Ouida, and their two older children in the crash of the Turkish plane in Paris on March 3, 1974, brought to a sudden end a career that had been characterized by swift attainment of professional recognition and personal success. That memorial services were held in the same week in New York, Washington, London, and Islamabad testifies to the achievements and the success; but as Professor Loren Graham stressed in his moving memorial address in the Riverside Church, while Wilcox took pleasure in his involvement in the great world, he was equally proud of his roots in rural America. His boyhood home, North Liberty, Indiana, was resonant with meaning for him. Born in 1932, he was educated in the local schools and he received his Bachelor of Science degree cum laude in Economics and Political Science from Purdue University in 1954 . He served in the Navy as a gunnery officer from 1954 to 1956.

Wilcox entered Columbia as a graduate student in 1956 , just when South Asian studies were beginning to penetrate the social sciences. His dissertation was one of the earliest scholarly works by an American on Pakistan, and this fact, combined with his lively intelligence, his remarkable gifts as a public speaker, and his willingness to generalize and predict, quickly won him a place among the bestknown analysts of South Asian affairs. Within a few years, he was in demand as a consultant on South Asia in the State Department and in other government agencies as well as for the Foundations interested in Asia. He travelled endlessly, addressing public meetings, taking part in conferences, but at the same time continuing to do research and write books and articles on South Asia.

Wilcox was an active participant in the Association for Asian Studies and he was slated to appear on a panel at the April meeting this year.

$\mathrm{He}$ was a Trustee of the American Institute of Indian Studies, and was one of those who, a decade ago, sought to create a similar Institute for Pakistan.

At Columbia, Wilcox was known to be a good teacher, despite the demands and excitement of his public role. He pushed hard and successfully for the establishment of the Southern Asian Institute, and it was largely through his efforts that the Pakistan Government established a Visiting Professorship at Columbia. In the autumn of 1968 , Wilcox became Chairman of the Department of Political Science. Professor Joseph Rothschild's comments at the memorial service as Chairman can stand as witness to Wilcox's work during this period:

"It was a most difficult and painful moment, when both the Department and the University at large were still deeply divided into angry camps in the aftermath of the previous spring's crisis. Positions were trumpeted as non-negotiable, tempers ran short, and moods were unforgiving. Combining, in equal measure, calm, cajolery, humor, guile, prudence, tolerance, and occasional pretences to amnesia, Wayne Wilcox (an old navy hand) steered us through this minefield and on a 
course that brought us to major changes in the Department's doctoral program, to new procedures for involving students in areas of departmental decision-making, and, most important, to a return to civility and goodwill. In retrospect, this emerges as a bigger and lonelier achievement than many of us appreciated at the time."

Of Wilcox's years as Cultural Attaché in London, a friend has written that Wayne and Ouida "played a spacious and inspiring role. The unusual combination of possibilities associated with their position put both of them at their very best, and their zest for life, their enthusiasm, and high intelligence brought the fruits of their imagination down to earth."

Their friends in the Association will remember them with gratitude and affection, while expressing deep sympathy to their two surviving children, Shelley and Spencer, and to their parents.

\section{Columbia University}

AinsLie T. EMBreE

New York 